\title{
On the ecology of Cletocamptus gomezi Suárez-Morales, Barrera-Moreno \& Ciros-Pérez 2013 (Crustacea, Copepoda, Harpacticoida) micro-endemic to Lake Alchichica, Central Mexico
}

\author{
Javier ALCOCER,,$^{*}$ María del Carmen HERNÁNDEZ, ${ }^{2}$ Luis A. OSEGUERA, ${ }^{1}$ Elva ESCOBAR ${ }^{3}$ \\ ${ }^{1}$ Universidad Nacional Autónoma de México, Facultad de Estudios Superiores Iztacala, Proyecto de Investigación en Limnología \\ Tropical, Av. de los Barrios No. 1, Los Reyes Iztacala, 54090 Tlalnepantla, Estado de México, México; ${ }^{2}$ Universidad Nacional \\ Autónoma de México, Programa de Posgrado en Ciencias del Mar y Limnología; ${ }^{3}$ Universidad Nacional Autónoma de México, \\ Instituto de Ciencias del Mar y Limnología, Ecología Marina y Biodiversidad, Laboratorio de Biodiversidad y Macroecología, \\ Ciudad Universitaria, A.P.70-305, 04510 México, D.F. \\ *Corresponding author: jalcocer@unam.mx
}

\begin{abstract}
Cletocamptus gomezi Suárez-Morales, Barrera-Moreno \& Ciros-Pérez (2013) is a recently described new species of meiobenthic Harpacticoida copepod, micro-endemic to Lake Alchichica, Puebla, Central Mexico. Cletocamptus gomezi lives in saline water $\left(K_{25}=12.6 \mathrm{mS} \mathrm{cm}^{-1}\right)$ dominated by sodium, magnesium, chloride, and bicarbonate ions and markedly alkaline (pH 9.0 \pm 0.1$)$. Cletocamptus gomezi occurs in a depth range of surface to $10 \mathrm{~m}$ with preference to shallow $(<3 \mathrm{~m}$ ), well oxygenated (above saturation) and warm $\left(>20^{\circ} \mathrm{C}\right)$ waters; fine sandy sediments $(2.3 \phi)$, rich in organic matter $(8.4 \%)$ and carbonate concentrations $(29 \%)$, and abundant aquatic vegetation coverage. In the littoral zone the average density and biomass of Cletocamptus gomezi reaches $4106 \pm 10,962$ ind $\mathrm{m}^{-2}$ and $3.66 \pm 9.75 \mathrm{mg} \mathrm{C} \mathrm{m}^{-2}$. Below $3 \mathrm{~m}$, along the lake's slope, the density reduces dramatically down to $265 \pm 593$ ind $\mathrm{m}^{-2}$ and $0.23 \pm 0.51 \mathrm{mg}$ $\mathrm{C} \mathrm{m}^{-2}$ at $10 \mathrm{~m}$. Cletocamptus gomezi is absent below $10 \mathrm{~m}$ down to $62 \mathrm{~m}$, the maximum depth of the lake. Spatially, except L3 (whose density and biomass values are the lowest) that differs $(P<0.05)$ from $L 4$ (whose density and biomass values are the highest), the littoral sampling stations are statistically similar in density and biomass $(P>0.5)$. Temporally, there are no statistical differences $(P>0.5)$ in density or biomass. The fact of finding Cletocamptus gomezi far away from the coast line (>100 km) and at high altitude (2335 $\mathrm{m}$ asl) is uncommon since most reports of Cletocamptus are from coastal brackish waters, and consequently, at sea level. Migrating waterbirds, as dispersal agents could be the explanation of Cletocamptus gomezi successfully inhabiting Lake Alchichica. Cletocamptus gomezi shares the same habitat with dense populations of tubificid oligochaetes, amphipods, leeches, chironomids, and nematodes. The disappearance of Cletocamptus gomezi habitat by the lake's -natural and mostly anthropogenic-desiccation process, seriously threatens the survival of this and the other numerous micro-endemic species of Lake Alchichica.
\end{abstract}

Key words: Tropical lake, oligotrophic lake, soda-alkaline lake, stromatolites, meiobenthos, endemism.

Received: August 2014. Accepted: October 2014

\section{INTRODUCTION}

Harpacticoida is the least known group of copepods; currently, there are 24 valid species in Cletocamptus (Gómez et al., 2007; Gómez and Gee, 2009). However, the Mexican inland waters lack studies to unravel the current diversity of the Harpacticoida fauna that waits to be discovered (Reid, 1990; Suárez-Morales and Reid, 1998).

Although Cletocamptus is a widely distributed genus with numerous records worldwide (Alonso, 1990; Gusakov and Gagarin, 2012), there are rather few reports of Cletocamptus from Mexican inland waters. Cole (1984) mentioned an Harpacticoida copepod similar to C. albuquerquensis from the Cuatro Ciénegas basin. Suárez-Morales et al. (1998) reported C. deitersi from a sinkhole (Cenote Grande) in Yucatán. Gómez et al. (2004) described C. sinaloensis, a new species from some lagoons and estuaries of Sinaloa (Ensenada del Pabellón lagoon, Yugo estuary, and Urias system). The last authors (Gómez et al., 2004) also suggested that the specimens of $C$. deitersi reported from the Yucatán sinkhole are most probably C. sinaloensis or C. deborahdexterae. Recently, Suárez-Morales et al. (2013) described a new species, Cletocamptus gomezi, from Lake Alchichica, Puebla. Up to date, there are just two confirmed species known from Mexico: Cletocamptus sinaloensis and Cletocamptus gomezi.

Most taxonomic descriptions of new species lack valuable environmental and ecological information; the accurate knowledge about the habitat and the environmental ranges and preferences of the newly described species is useful to compare with those from other similar species and could help in deciding about their true taxonomic identity. The present paper outlines the habitat characteristics and general ecology of Cletocamptus gomezi, the 
newly described and micro-endemic Harpacticoida species inhabiting Lake Alchichica.

\section{Study area}

Lake Alchichica is located at $19^{\circ} 24^{\prime} \mathrm{N}$ and $97^{\circ} 24^{\prime} \mathrm{W}$, in the Oriental basin at the border of the states of Puebla, Tlaxcala and Veracruz, at an altitude of $2335 \mathrm{~m}$ asl. The annual air temperature fluctuates from -5.5 to $30^{\circ} \mathrm{C}$ with a mean value of $14.4^{\circ} \mathrm{C}$. The climate is semi-arid, with an annual precipitation of less than $500 \mathrm{~mm}$, and an annual evaporation rate of $1690 \mathrm{~mm}$ (Adame et al., 2008).

The lake is almost circular (area $2.3 \mathrm{~km}^{2}$ ), with a circumference of $5.1 \mathrm{~km}$ and a diameter of approximately $1.7 \mathrm{~km}$. It is a deep lake with a maximum depth of $62 \mathrm{~m}$ and a mean depth of $40.9 \mathrm{~m}$ (Filonov et al., 2006). The lake basin contains saline (salinity $8.5 \pm 0.52 \mathrm{~g} \mathrm{~L}^{-1}$, conductivity $13 \pm 0.5 \mathrm{mS} \mathrm{cm} \mathrm{cm}^{-1}$ ) and alkaline $(\mathrm{pH}$ 8.7-9.2) water, dominated by chloride, bicarbonate, sodium and magnesium ions (Armienta et al., 2008). Alchichica is a warm, monomictic lake with a mixing period during the cold, dry season (late December/early January to late March/early April) and a stratification period that lasts throughout the warm, rainy season (Alcocer et al., 2000). During the winter circulation period dissolved oxygen (DO) approaches saturation throughout the water column. As soon as the lake stratifies, the hypolimnetic waters close to the bottom became anoxic. From May to December the hypolimnion was completely anoxic.

Interestingly, Alchichica is inhabited by a large number of endemic (micro-endemic) species. Up to date, it could be mentioned the Atherinopsidae fish Poblana alchichica (de Buen, 1945), the Corixidae insect Krizousacorixa tolteca (Jansson, 1979), the Ambystomatidae amphibian Ambystoma taylori (Brandon et al., 1981), the Isopoda crustacean Caecidotea williamsi (Escobar-Briones and Alcocer, 2002), the Diatom algae Cyclotella alchichicana (Oliva et al., 2006), the Diaptomidae copepod Leptodiaptomus garciai (Montiel-Martínez et al., 2008), the Harpacticoida copepod Cletocamptus gomezi (Suárez-Morales et al., 2013), and the Limnocytheridae ostracod Limnocytherina axalapasco (Cohuo-Durán et al., 2014).

\section{METHODS}

The steep bathymetry of the lake (bucket like), characteristic of the maar-type lakes, required a sampling program covering the three main regions of the lake: i) the shallow $(\leq 5 \mathrm{~m})$ and reduced littoral zone; ii) the steep slope (5-50 $\mathrm{m})$; and iii) the extend deep (50-62 m) and flat area. In the littoral and in the deep benthic zones three replicate samples (top $10 \mathrm{~cm}$ only) of benthic fauna were collected with an Ekman-type grab sampler $\left(0.0225 \mathrm{~m}^{2}\right.$ area, $\left.15 \times 15 \mathrm{~cm}\right)$ at each sampling station. The rocky nature of the stromatolites and surrounding substrate that constitutes the lake's slope prevented the use of an Ekman grab. It was necessary to implement a SCUBA diving sampling program. Divers took by hand three replicate samples with a manual corer $\left(0.0050 \mathrm{~m}^{2}, 4 \mathrm{~cm}\right.$ in diameter $)$.

We established five stations in the littoral area to recognize the heterogeneity created by the different degree of communication between the littoral zone and the main water body generated by the presence of the stromatolites ring (i.e., from complete communication to almost isolated from the limnetic zone, and from totally exposed to wave action to well-protected: L3, L2, L1, L5 and L4) (Fig. 1). Eight sampling depths were chosen along the slope, $(3,5,10,13,15,21,25$ and $28 \mathrm{~m})$ according to availability since an almost vertical calcareous deposit composes most of the slope (Fig. 1). Logistics (high-altitude diving, complete darkness) limits diving deeper than $30 \mathrm{~m}$, so the $30-50 \mathrm{~m}$ depth range in the slope was avoided. Since the slope is almost vertical, it was possible to sample only where a shelf-like rocky projection allows the sediment to accumulate, thus providing a substrate for the benthos to establish.

Finally, four stations $(50 \mathrm{~m}, 60 \mathrm{~m}, 61 \mathrm{~m}$ and $62 \mathrm{~m})$ were established to represent an offshore-bathymetric gradient into the deep zone. The station nearest to shore was located approximately $175 \mathrm{~m}$ from the shore, and the station farthest from shore, at the center of the lake, was located at a distance of approximately $900 \mathrm{~m}$ (Fig. 1). Five (March, May, July, September and November), twelve (January to December) and one (September) sampling dates were considered in the littoral, the deep zone and the slope, respectively.

Each sediment sample was sieved in situ through a $0.062 \mathrm{~mm}$ mesh pore size to retain meiofauna (Gray, 1981; Wetzel, 2001). The samples were preserved in $96 \%$ alcohol and Bengal Rose as a vital dye (APHA et al., 1985). The specimens of Cletocamptus gomezi were handpicked under the microscope, and quantified to determine their density (ind $\mathrm{m}^{-2}$ ). The biomass was calculated following the biovolume method (Warwick and Price, 1979; Higgins and Thiel, 1988). The biovolume (nL) was transformed into preserved wet weight, dry weight and carbon using the conversion factors proposed by Gerlach (1971), Feller and Warwick (1988) and Giere (1993), respectively. Environmental water variables (temperature, $\mathrm{pH}, \mathrm{DO}$ and salinity) and sediment (particle size, organic matter content, carbonate, vegetation coverage) were measured as described in Hernández et al. (2010, 2014).

Since transformed $\left[\log _{10}(n+1)\right]$ biological data of the littoral area does not fulfill the statistic parametric assumptions (normal distribution, homogeneous variances), we used the non-parametric Kruskall-Wallis (significance $\mathrm{P}<0.05$ ) followed by Dunn's multiple comparison (significance $\mathrm{P}<0.05$ ) tests (Statistica v. 7.0) to identify spatial and temporal differences. 


\section{RESULTS}

Comparatively with the deep benthic area that resulted quite homogeneous, the littoral zone is heterogeneous (Tab. 1). Besides $\mathrm{pH}$, the rest of the water parameters differ from one station to the others. The sediment texture ranges from fine to coarse sand with moderate to high organic matter and carbonate content. The aquatic vegetation coverage ranges from totally naked to fully cover with macrophytes (Ruppia maritima and Cyperus laevigatus) and benthic algae (filamentous chlorophytes and cyanobacteria, diatoms).
No sediment characterization was carried out on the slope, just of the water column characteristics due to the limited availability of sediment. From surface down to 10 $\mathrm{m}$, it corresponds to the mixing zone, which resulted, as expected, homogeneous (Tab. 1). The deep benthic area of Lake Alchichica is stable (Tab. 1) with exception of the DO that is present only for four months (February-May), while the rest of the year the bottom water remains anoxic and $\mathrm{H}_{2} \mathrm{~S}$ reaches up to $3.08 \mathrm{mg} \mathrm{L}^{-1}$ (Hernández et al., 2014). The substrate presented fine sediments with very high contents of organic matter, and carbonate. As ex-
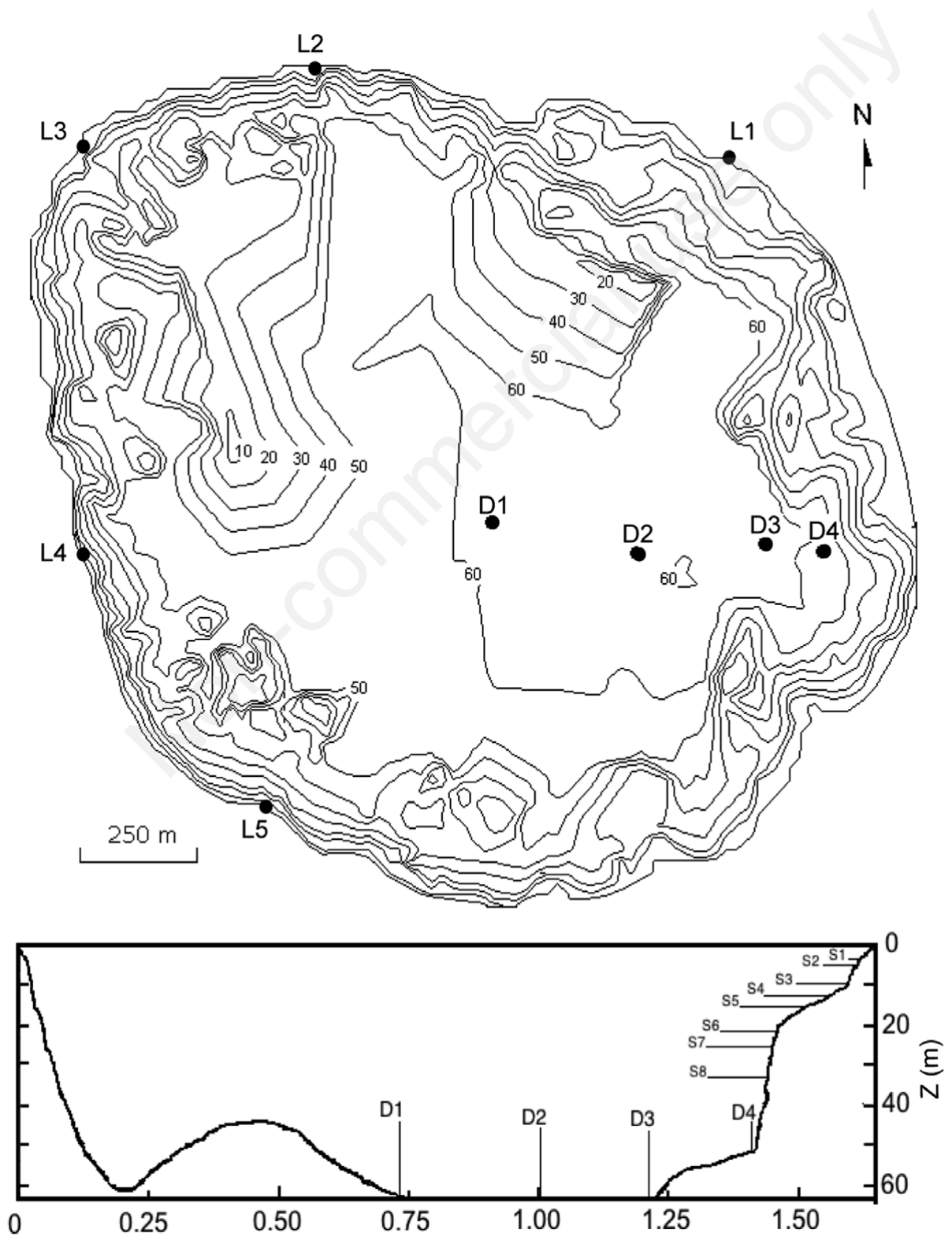

Fig. 1. Lake Alchichica bathymetric map (upper panel) and bathymetric profile showing the location of the sampling stations (littoral zone, L1 to L5; slope, S1 to S8; deep benthic area, D1 to D4). 
pected, no vegetation is present beyond the euphotic zone (30 $\mathrm{m}$ at most).

Cletocamptus gomezi inhabits the entire littoral area, which makes up $10.5 \%$ and $0.7 \%$ of the global littoral meiobenthic density and biomass, respectively. Cletocamptus gomezi displays different densities ranging from $159 \pm 356$ ind $\mathrm{m}^{-2}$ (L3) to $10,451 \pm 10,789$ ind $\mathrm{m}^{-2}$ (L4) (Fig. 2); the global average density of the littoral area is $4106 \pm 10,962$ ind $\mathrm{m}^{-2}$. The biomass fluctuates from $0.1 \pm 0.33 \mathrm{mg} \mathrm{C} \mathrm{m}^{-2}$ (L3) to $9.07 \pm 9.39 \mathrm{mg} \mathrm{C} \mathrm{m}^{-2}$ (L4) (Fig. 2); the average of the littoral area is $3.66 \pm 9.75 \mathrm{mg} \mathrm{C} \mathrm{m}^{-2}$. Excepting L3 (lowest density and biomass values) that resulted statistically different $(\mathrm{P}<0.05)$ from L4 (highest density and biomass values), littoral sampling stations are statistically similar in density and biomass $(\mathrm{P}>0.5)$. Patchiness of Cletocamptus gomezi explains the large standard deviations clearly appreciated in Fig. 2. November shows the lowest density values $\left(796 \pm 1754\right.$ ind $\left.\mathrm{m}^{-2}\right)$ while September the highest
$8700 \pm 13,909$ ind $\mathrm{m}^{-2}$. The same is true for biomass with $0.79 \pm 1.68 \mathrm{mg} \mathrm{C} \mathrm{m}^{-2}$ in November and $7.67 \pm 12.27 \mathrm{mg} \mathrm{C}$ $\mathrm{m}^{-2}$ in September (Fig. 2). Graphically, temporal differences in density and biomass could be appreciated with the highest values in July and the lowest in November (Fig. 2); nonetheless, there are no statistically differences $(\mathrm{P}>0.05)$ among sampling dates.

Sampling station L4, where the largest densities and biomass of Cletocamptus gomezi were found, shows the lowest values of $\mathrm{pH}$ and salinity, with the highest of $\mathrm{DO}$ concentration, temperature, and organic matter and carbonate concentrations, vegetation coverage and the finest sediment texture (fine sands). The range of the physical and chemical parameters where Cletocamptus gomezi lives is provided in Tab. 2. Along the slope the presence of Cletocamptus gomezi shows a diminishing trend from $3 \mathrm{~m}$ down to $10 \mathrm{~m}$; below this depth and all the way down to $28 \mathrm{~m}$ specimens are absent (Fig. 2). It should be noted that

Tab. 1. Environmental setting of the benthic area of Lake Alchichica.

\begin{tabular}{|c|c|c|c|c|c|c|c|c|c|c|c|}
\hline \multicolumn{2}{|l|}{ Water } & \multirow{2}{*}{$\begin{array}{c}\text { L1 } \\
9.0 \pm 0.1\end{array}$} & \multirow{2}{*}{$\begin{array}{c}\mathrm{L} 2 \\
9.0 \pm 0.1\end{array}$} & \multirow{2}{*}{$\begin{array}{c}\text { L3 } \\
9.0 \pm 0.1\end{array}$} & \multirow{2}{*}{$\begin{array}{c}\mathrm{L} 4 \\
8.9 \pm 0.1\end{array}$} & \multirow{2}{*}{$\begin{array}{c}\text { L5 } \\
9.0 \pm 0.1\end{array}$} & \multirow{2}{*}{$\begin{array}{c}\text { Slope } \\
9.2 \pm 0.1\end{array}$} & \multirow{2}{*}{$\begin{array}{c}\text { D1 } \\
9.2 \pm 0.1\end{array}$} & \multirow{2}{*}{$\begin{array}{c}\text { D2 } \\
9.2 \pm 0.1\end{array}$} & \multirow{2}{*}{$\begin{array}{c}\text { D3 } \\
9.1 \pm 0.1\end{array}$} & \multirow{2}{*}{$\begin{array}{c}\text { D4 } \\
9.1 \pm 0.2\end{array}$} \\
\hline $\mathrm{pH}$ & $\mathrm{pH}$ units & & & & & & & & & & \\
\hline DO & $\mathrm{mg} \mathrm{L}^{-1}$ & $7.3 \pm 1.1$ & $6.5 \pm 1.2$ & $6.5 \pm 1.6$ & $12.3 \pm 1.9$ & $9.1 \pm 2.5$ & $6.5 \pm 0.2$ & $3.9 \pm 1.1$ & $3.9 \pm 1.1$ & $3.9 \pm 1.1$ & $4.2 \pm 1.4$ \\
\hline Temp & ${ }^{\circ} \mathrm{C}$ & $20.4 \pm 0.7$ & $18.3 \pm 4.0$ & $20.0 \pm 1.3$ & $24.9 \pm 1.3$ & $19.9 \pm 1.7$ & $17.3 \pm 0.2$ & $14.5 \pm 0.1$ & $14.5 \pm 0.1$ & $14.5 \pm 0.1$ & $14.5 \pm 0.1$ \\
\hline $\mathrm{K}_{25}$ & $\mathrm{mS} \mathrm{cm}{ }^{-1}$ & $12.9 \pm 0.2$ & $12.9 \pm 0$ & $13.2 \pm 0.7$ & $11.0 \pm 1.5$ & $12.8 \pm 0.5$ & $12.9 \pm 0.1$ & $13.9 \pm 0.7$ & $13.9 \pm 0.7$ & $13.9 \pm 0.7$ & $13.9 \pm 0.7$ \\
\hline \multicolumn{2}{|c|}{ Sediment } & L1 & L2 & L3 & L4 & L5 & Slope & D1 & D2 & D3 & D4 \\
\hline Organic matter & $\%$ & $5.6 \pm 2.9$ & $5.0 \pm 2.6$ & $2.8 \pm 1.9$ & $8.4 \pm 6.2$ & $6.4 \pm 4.3$ & nd & $31 \pm 2$ & $33 \pm 3$ & $38 \pm 3$ & $37 \pm 1$ \\
\hline $\mathrm{CO}_{3}$ & $\%$ & $1.9 \pm 0.2$ & $3.2 \pm 0.8$ & $3.7 \pm 1.1$ & $29 \pm 1.9$ & $18.3 \pm 4.5$ & nd & $10.7 \pm 2.3$ & $12.9 \pm 2.8$ & $15.7 \pm 3.4$ & $15.0 \pm 4.2$ \\
\hline Texture & $\phi$ & $0.2 \pm 0$ & $1.6 \pm 0$ & $1.3 \pm 0$ & $2.3 \pm 0$ & $1.7 \pm 0$ & nd & $5.9 \pm 1.2$ & $5.4 \pm 1.9$ & $5.2 \pm 1.5$ & $5.1 \pm 1.6$ \\
\hline $\begin{array}{l}\text { Submersed } \\
\text { macrophytes }\end{array}$ & $\%$ & 25 & 0 & 0 & 100 & 75 & $0-40$ & 0 & 0 & 0 & 0 \\
\hline Benthic algae & $\%$ & 0 & 0 & 0 & 0 & 25 & $0-25$ & 0 & 0 & 0 & 0 \\
\hline
\end{tabular}

$L$, littoral benthic stations; slope, 0-10 m, mixing zone; $D$, deep benthic stations; $D O$, dissolved oxygen; Temp, water temperature; $K_{25}$, conductivity standardized at $25^{\circ} \mathrm{C} ; \mathrm{CO}_{3}$, carbonates; $n$, not determined.

Tab. 2. Minimum and maximum values of the environmental factors of the habitats in which the species Cletocamptus gomezi occurs in Lake Alchichica, Puebla. The average values ( \pm standard deviation) are included where the highest densities and biomasses of the species occur are provided (L4).

\begin{tabular}{|c|c|c|c|c|}
\hline \multicolumn{2}{|l|}{ Water } & \multirow{2}{*}{$\begin{array}{c}\text { Minimum } \\
8.9\end{array}$} & \multirow{2}{*}{$\begin{array}{c}\text { Maximum } \\
9.2\end{array}$} & \multirow{2}{*}{$\begin{array}{c}\mathrm{L} 4 \\
8.9 \pm 0.1\end{array}$} \\
\hline $\mathrm{pH}$ & $\mathrm{pH}$ units & & & \\
\hline DO & $\mathrm{mg} \mathrm{L}^{-1}$ & 6.5 & 12.3 & $12.3 \pm 1.9$ \\
\hline Temp & ${ }^{\circ} \mathrm{C}$ & 19.9 & 24.9 & $24.9 \pm 1.3$ \\
\hline $\mathrm{K}_{25}$ & $\mathrm{mS} \mathrm{cm}{ }^{-1}$ & 11 & 13.2 & $11 \pm 1.5$ \\
\hline \multicolumn{2}{|l|}{ Sediment } & Minimum & Maximum & L4 \\
\hline Organic matter & $\%$ & 2.8 & 8.4 & $8.4 \pm 6.2$ \\
\hline $\mathrm{CO}_{3}$ & $\%$ & 1.69 & 29 & $29 \pm 1.9$ \\
\hline Texture & $\phi$ & 0.2 & 2.3 & $2.3 \pm 0$ \\
\hline Submersed macrophytes & $\%$ & 0 & 100 & $100 \pm 0$ \\
\hline Benthic algae & $\%$ & 0 & 25 & 0 \\
\hline
\end{tabular}

Temp, water temperature; $\mathrm{K}_{25}$, conductivity standardized at $25^{\circ} \mathrm{C} ; \mathrm{CO}_{3}$, carbonates. 
other organisms -ostracods, chironomids and acarids- are present between 10 and $28 \mathrm{~m}$. At $3 \mathrm{~m}$ the density of Cle-

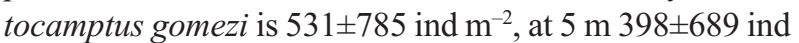

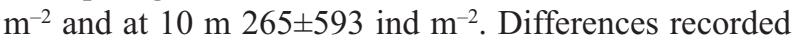
are large $(3.6 \%)$ between the average density in the littoral $\left(4106 \pm 10,962\right.$ ind $\left.^{-2}\right)$ and the slope $\left(149 \pm 258\right.$ ind $\left.^{-2}\right)$ in Lake Alchichica. Regarding biomass, the trend is similar with $0.45 \pm 0.67 \mathrm{mg} \mathrm{C} \mathrm{m}^{-2}$ at $3 \mathrm{~m}, 0.34 \pm 0.59 \mathrm{mg} \mathrm{C} \mathrm{m}^{-2}$ at 5 $\mathrm{m}$ and $0.23 \pm 0.51 \mathrm{mg} \mathrm{C} \mathrm{m}^{-2}$ at $10 \mathrm{~m}$. The difference in den-
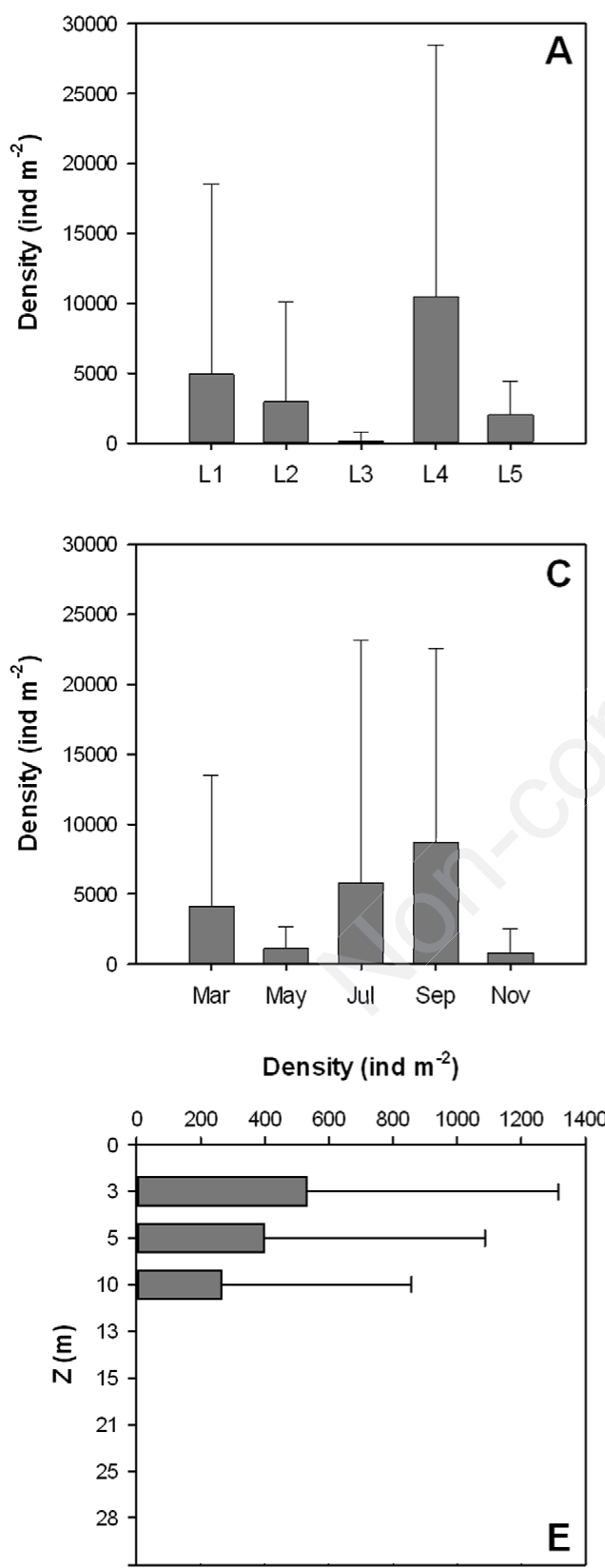

sity between the littoral and the slope is the same in the biomass trends (3.6\%) with $3.66 \pm 9.75 \mathrm{mg} \mathrm{C} \mathrm{m}^{-2}$ in the littoral and $0.13 \pm 0.22 \mathrm{mg} \mathrm{C} \mathrm{m}^{-2}$ in the slope. Below $28 \mathrm{~m}$ and down to $50 \mathrm{~m}$, along the steep slope, sampling was not carried out, however, along the extended deep benthic zone (50-62 m) where sampling was achievable, Cletocamptus gomezi was absent in spite of the presence of other organisms -ostracods and chironomids- found in the deep benthos $(\geq 50 \mathrm{~m})$ of Lake Alchichica.
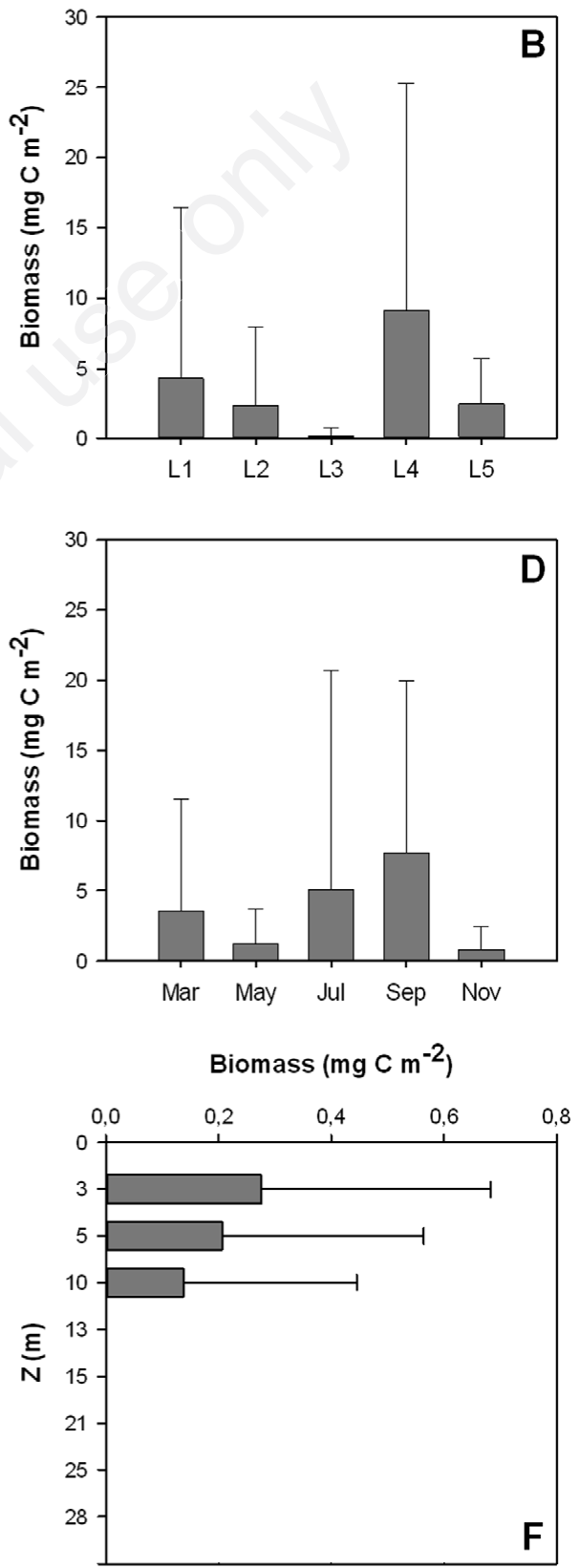

Fig. 2. Density (A, C, E) and biomass (B, D, F) distributions of Cletocamptus gomezi: in the littoral (upper and middle panels), and on the benthic slope of Lake Alchichica, Mexico. 


\section{DISCUSSION}

Cletocamptus gomezi is a micro-endemic species, restricted to Lake Alchichica. This category (micro-endemism) applies to species with limited distribution in Mexico ( $<5 \%$ of the Mexican territory). Alchichica surface area $\left(2.3 \mathrm{~km}^{2}\right)$ is $0.0001 \%$ of the Mexican territory $\left(1.96 \times 10^{6} \mathrm{~km}^{2}\right)$. It is clear that Cletocamptus gomezi is a littoral species that can spread down to $10 \mathrm{~m}$ deep, where its numbers diminish abruptly (down to $6.5 \%$ those found in the littoral). The largest abundance and biomass occurrence of Cletocamptus gomezi (i.e., L4) is most probably related to: i) food availability and ii) high levels of DO. Harpacticoids require high availability of organic matter to grow. Although most freshwater Harpacticoida species have been classified as detritus feeders, specifically some species seem to benefit from the presence of diatoms and some species evidently feed on bacteria (Sarvala, 1998). It is probable that the littoral species are more dependent on fresh algal material (Sarvala, 1979). On the other hand, Harpacticoida prefer soft organic bottoms of the lower littoral zone (1-2 m) with well-oxygenated water since the are especially sensitive to oxygen depletion in sediment (Hicks and Coull, 1983), and for this reason they are confined to the upper centimeters in tropical habitats (Somerfield et al., 1998; Zhou, 2001). Strong hydrodynamics (breaking waves and water currents), coarse sediments, lack of vegetation, and low organic matter availability are unfavorable conditions for Harpacticoida to prosper (Raspopov et al., 1996); all these characteristics describe L3, the station with the lowest density and biomass values of Cletocamptus gomezi.

The limited bathymetric distribution of Cletocamptus gomezi along the lake's slope (Fig. 2) is certainly not a function of the DO concentration. According to Ardiles et al. (2012), the mixed layer in Lake Alchichica ranged from $12 \mathrm{~m}$ during the early stratification down to the whole water column throughout the circulation period. DO concentration, initially low $\left(4.0 \mathrm{mg} \mathrm{L}^{-1}\right)$ at the beginning of the circulation period, rapidly increases $(7.2 \mathrm{mg}$ $\mathrm{L}^{-1}$ ) during the early stratification and remains around saturation $\left(6.5 \mathrm{mg} \mathrm{L}^{-1}\right)$ for the rest of the stratification period. Then, at $10 \mathrm{~m}$ deep, the water column remains oxygenated throughout the year. Food availability seems not to be the answer to the limited bathymetric distribution of Cletocamptus gomezi. The benthic diatoms that cover the stromatolites constitute a fresh, high quality and plentiful food source for benthic feeders such as Cletocamptus gomezi.

On the other hand, as mentioned before, the rocky nature of the stromatolites and its surrounding substrate and the steep cliff makes complicated to colonize this substrate. The only species that has been found so far taking advantage of this apparently unfavorable substrate is the Asellidae isopod Caecidotea williamsi, micro-endemic to Lake Alchichica, that lives cryptically within the tufa (stromatolites) crevices and nowhere else in the lake (Escobar-Briones and Alcocer, 2002). Benthos was found only in those shelf-like projections (or large cavities) on the stromatolites, which allow sediment accumulation. However, as mentioned above, other species - but not Cletocamptus gomezi - are found along the slope at greater depths. Finally, at and below $50 \mathrm{~m}$, only two species are found: an ostracod and a chironomid (Hernández et al., 2014). Both species are regulated by the long period ( 8 months) of anoxia and the presence of $\mathrm{H}_{2} \mathrm{~S}$ at these depths.

The fact that Cletocamptus gomezi inhabits in a saline lake is unimportant since this is a genus of marine origin that has been reported from fresh (rarely), brackish (mostly) and hypersaline waters (Boxshall and Defaye, 2008; Gómez et al., 2004 and 2007; Mielke, 2000). On the other hand, as stressed by Suárez-Morales et al. (2013), the fact of finding Cletocamptus gomezi in saline waters but far away from the coastline $(>100 \mathrm{~km}$ in straight line) and in high altitude ( $2300 \mathrm{~m}$ asl) could be uncommon. Most reports of Cletocamptus are from brackish habitats related to estuaries and coastal lagoons, at sea level. Another similar report places C. cecsurirensis at even higher altitude (4245 m asl) at the Salar de Surire, Chile. The Harpacticoida assemblages tend to be homologous in similar habitats where the same families of genera are associated to similar ecological conditions (Ceccerelli and Mistri, 1990).

Some authors (Havel and Shurin, 2004; Frisch et al., 2007) have suggested that coastal waterbirds can be the main dispersing agents for invertebrates from brackish environments, surviving the digestion process of birds (Green and Figuerola, 2005) and waterfowl feet and plumage (Figuerola and Green, 2002). Diverse waterbirds are commonly found in Lake Alchichica such as Aythya affinis, Oxyura jamaicensis, Podiceps nigricollis, Calidris minutilla, C. bairdii, C. mauri and Fulica americana, and occasionally (personal observations), seagulls and even pelicans could be seen. Some of these species migrate from long distances (e.g., Canada). Quantifying the viability of this aquatic invertebrate in the feces, plumage and feet of the wintering bird species still remains to be carried out. Cletocamptus gomezi shares the same habitat with dense populations of tubificid oligochaetes (mostly Limnodrilus hoffmesiteri), amphipods (Hyalella azteca), leeches, chironomids [mostly Tanypus (Apelopia) and Stictochironomus], and nematodes (Semitobrilus, Monhystera, Neotobrilus, Daptonema, Paracyatolaimus).

The following organisms mentioned by Alcocer $e t$ al. (1998) to inhabit Alchichica's littoral area, could be considered potential predators of Cletocamptus gomezi. The damselfly Enallagma praevarum, the dragonfly Aeshna dugesi, hemipterans of the genera Buenoa and Ambrysus, coleopterans of the genera Stenus, Hydroporus and Laccodytes, and dipteran tanypodids of the genera Tanypus 
(Apelopia), Micropsectra, and species Labrudinia pilosela. Even the small larvae of the endemic silverside Poblana alchichica could be feeding on Cletocamptus gomezi; harpacticoids copepods are known to be the primary food source for bottom or phytal feeding juvenile and small fish (Wyckmans et al., 2007). They represent an important link between microalgal primary production and higher trophic levels (Andersen et al., 2005).

\section{CONCLUSIONS}

The most important impact on the aquatic biota of Lake Alchichica, Cletocamptus gomezi included, is the lake's desiccation process. The reduction of the lake's water level has been documented through studies as well as historical aerial photographs. The natural long-term trend to higher temperatures and lower precipitations is being overshadowed by a growing human (urban, agriculture, industry) development demanding water from a semi-desert basin. Unfortunately, the originally extended, shallow littoral zone has drastically reduced and a large portion of the stromatolite deposits, formerly submersed, are today exposed to sunlight, dry and devoid of aquatic life. The disappearance of Cletocamptus gomezi habitat, seriously threatens the survival of this and the other numerous micro-endemic species of Lake Alchichica.

\section{ACKNOWLEDGEMENTS}

This project was financially supported by Consejo $\mathrm{Na}-$ cional de Ciencia y Tecnología (CONACyT) project 103332, Dirección General de Asuntos del Personal Académico de la UNAM (DGAPA) PAPIIT project IN215512 and UNAM FES Iztacala project PAPCA 2013. We are greatly indebted to V.E. Urbieta (Facultad de Medicina, UNAM) and her diving team for support in the fieldwork.

\section{REFERENCES}

Adame MF, Alcocer J, Escobar E, 2008. Size fractionated phytoplankton biomass and its implications for the dynamics of an oligotrophic tropical lake. Freshwater Biol. 53:22-31.

Alcocer J, Escobar E, Lugo A, Peralta L, 1998. Littoral benthos of the saline crater-lakes of the basin of Oriental, Mexico. Int. J. Salt Lake Res. 7:87-108.

Alcocer J, Lugo A, Escobar E, Sánchez MR, Vilaclara G, 2000. Water column stratification and its implications in the tropical warm monomictic Lake Alchichica, Puebla, Mexico. Verh. Int. Verein. Limnol. 27:3166-3169.

Alonso M, 1990. Anostraca, Cladocera and Copepoda of Spanish saline lakes. Hydrobiologia 197:221-231.

Andersen BS, Carl JD, Grønkjær P, Støttrup JG, 2005. Feeding ecology and growth of age 0 year Platichthys flesus (L.) in a vegetated and a bare sand habitat in a nutrient rich fjord. J. Fish Biol. 66:531-552.

APHA, AWWA, WPCF, 1985. Standard methods for the exam- ination of water and wastewater. American Public Health Association: 1193 pp.

Ardiles V, Alcocer J, Vilaclara G, Oseguera LA, Velasco L, 2012. Diatom fluxes in a tropical, oligotrophic lake dominated by large-sized phytoplankton. Hydrobiologia 679:77-90.

Armienta MA, Vilaclara G, de la Cruz-Reyna S, Ramos S, Ceniceros N, Cruz O, Aguayo A, Arcega-Cabrera F, 2008. Water chemistry of lakes related to active and inactive Mexican volcanoes. J. Volcan. Geothermal Res. 178:249-258.

Boxshall GA, Defaye D, 2008. Global diversity of copepods (Crustacea: Copepoda) in freshwater. Hydrobiologia 595:195-207.

Brandon RA, Maruska EJ, Rumph WT, 1981. A new species of neotenic Ambystoma (Amphibia, Caudata) endemic to Laguna Alchichica, Puebla; México. Bull. Southern Calif. Acad. Sci. 80: 112-125.

Ceccerelli VU, Mistri M, 1990. Ecological and zoogeographical study of some Mediterranean associations of brackish water harpacticoids. Boll. Zool. 57:73-81.

Cohuo-Durán S, Pérez L, Karanovic I, 2014. On Limnocytherina axalapasco, a new freshwater ostracods (Podocopida: Limnocytheridae) from Mexican crater lakes. Rev. Biol. Trop. 62:15-32.

Cole GA, 1984. Crustacea from the Bolsón of Cuatro Ciénegas, Coahuila, México. J. Arizona-Nevada Acad. Sci. 19:3-12.

de Buen F, 1945. [Investigaciones sobre ictiología mexicana. I. Atherinidae de aguas continentales de México].[Article in Spanish]. Anales del Instituto de Biología, Univ. Nat. Autón. Mex. 16:475-532.

Escobar-Briones E, Alcocer J, 2002. Caecidotea williamsi (Crustacea: Isopoda: Asellidae), a new species from a saline crater-lake in the eastern Mexican Plateau. Hydrobiologia 477:93-105.

Feller JR, Warwick RM, 1988. Energetics, p. 181-196. In: R.P. Higgins and H. Thiel (eds.), Introduction to the study of meiofauna. Smithsonian Institution Press.

Figuerola J, Green AJ, 2002. Dispersal of aquatic organisms by waterbirds: a review of past research and priorities for future studies. Freshwater Biol. 47:483-494.

Filonov A, Tereshchenko I, Alcocer J, 2006. Dynamic response to mountain breeze circulation in Alchichica, a crater lake in Mexico. Geophys. Res. Lett. 33:L07404.

Frisch D, Green AJ, Figuerola J, 2007. High dispersal capacity of a broad spectrum of aquatic invertebrates via waterbirds. Aquat. Sci. 69:568-574.

Gerlach SA, 1971. On the importance of marine meiofauna for benthos communities. Oecologia 6:176-190.

Giere O, 1993. The microscopic fauna in aquatic sediments. Springer: $328 \mathrm{pp}$.

Gómez S, Fleeger JW, Rocha-Olivares A, Foltz D, 2004. Four new species of Cletocamptus Schmankewitsch, 1875, closely related to Cletocamptus deitersi (Richard, 1897) (Copepoda: Harpacticoida). J. Nat. Hist. 38:2669-2732.

Gómez S, Gee JM, 2009. On four new species of Cletocamptus Shmankevich, 1875 (Copepoda: Harpacticoida) from inland waters of Argentina J. Nat. Hist. 43:2853-2910.

Gómez S, Scheihing R, Labarca P, 2007. A new species of Cletocamptus (Copepoda: Harpacticoida) from Chile and some notes on Cletocamptus axi Mielke, 2000. J. Nat. Hist. 41:39-60.

Gray JS, 1981. The ecology of marine sediments. Cambridge studies in modern biology. 2. Cambridge University Press: 185 pp. 
Green AJ, Figuerola J, 2005. Recent advances in the study of long-distance dispersal of aquatic invertebrates via birds. Diver. Distrib. 11:49-156.

Gusakov VA, Gagarin VG, 2012. Meiobenthos composition and structure in highly mineralized tributaries of Lake El'ton. Arid EkosistemS 18:45-54.

Havel JE, Shurin JB, 2004. Mechanisms, effects, and scales of dispersal in freshwater zooplankton. Limnol. Oceanogr. 49:1229-1238.

Hernández MC, Alcocer J, Oseguera LA, Escobar E, 2014. Profundal benthic invertebrates in an oligotrophic tropical lake: different strategies for coping with anoxia. J. Limnol. 73:387-399.)

Hernández MC, Escobar E, Alcocer J, 2010. [Ensamble de crustáceos bentónicos en un lago salino tropical].[Article in Spanish]. Rev. Mex. Biodiver. 81:133-140.

Hicks GRF, Coull BC, 1983. The ecology of marine meiobenthic harpacticoid copepods. Oceanogr. Mar. Biol. Ann. Rev. 21: 167-175.

Higgins RP, Thiel H, 1988. Introduction of meiofauna. Smithsonian Institution Press, Washington: 488 pp.

Jansson A, 1979. A new species of Krizousacorixa from Mexico (Heteroptera, Corixidae). Pan-Pacific Entomologist 55:258260.

Mielke W, 2000. Two new species of Cletocamptus (Copepoda: Harpacticoida) from Galápagos, closely related to the Cosmopolitan C. deitersi. J. Crustacean. Biol. 20:273-284.

Montiel-Martínez A, Ciros-Pérez J, Ortega-Mayagoitia E, ElíasGutiérrez M, 2008. Morphological, ecological, reproductive and molecular evidence for Leptodiaptomus garciai (Osorio-Tafall 1942) as a valid endemic species. J. Plankton Res. 30:1079-1093.

Oliva MG, Lugo A, Alcocer J, Cantoral-Uriza EA, 2006. Cyclotella alchichicana sp. nov. from a saline Mexican lake. Diatom Res. 21:81-89.

Raspopov IM, Andronikova IN, Dotsenko ON, Kurashov EA,
Letanskaya GI, Panov VE, Rychkova MA, Telesh IV, Tchernykh OA, Vorontsov FF, 1996. Littoral zone of Lake Ladoga: ecological state evaluation. Hydrobiologia 322:39-47.

Reid JW, 1990. [Continental y costera copépodos (Crustáceos ) de México, América Central y la región del Caribe, p.175213]. In: D. Navarro and J. G. Robinson (eds.), [Diversidad Biológica en la Reserva de la Biosfera de Sian Ka'an, Quintana Roo, México].[Book in Spanish]. CIQRO/University of Florida.

Sarvala J, 1979. Effect of temperature on the duration of egg, naupliar and copepodite development of some freshwater benthic Copepoda. Freshwater Biol. 9:515-534.

Sarvala J, 1998. Ecology and role of benthic copepods in northern lakes. J. Marine Syst. 15:75-86.

Somerfield PJ, Gee JM, Aryuthaka C, 1998. Meiofaunal communities in a Malaysian mangrove forest. J. Mar. Biol. As. UK 78:717-732.

Suárez-Morales E, Barrera-Moreno O, Ciros-Pérez, 2013. A new species of Cletocamptus Schmankewitsch, 1875 (Crustacea, Copepoda, Harpacticoida) from a high altitude saline lake in Central Mexico. J. Limnol. 72:313-325.

Suárez-Morales E, Reid JW, 1998. An updated list of the freeliving freshwater copepods (Crustacea) of Mexico. Southwest. Nat. 43:256-265.

Warwick RM, Price R, 1979. Ecological and metabolic studies of free-living nematodes from an estuarine mud-flat. Estuar. Coast. Mar. Sci. 9:257-271.

Wetzel RG, 2001. Limnology: lake and river ecosystems. Academic Press: 1006 pp.

Wyckmans M, Chepurnov VA, Vanreusel A, De Troch M, 2007. Effects of food diversity on diatom selection by harpacticoid copepods. J. of Exp. Mar. Biol. Ecol. 345:119-128.

Zhou H, 2001. Effects of leaf litter addition on meiofaunal colonization of azoic sediments in a subtropical mangrove in Hong-Kong. J. Exp. Mar. Biol. Ecol. 256:99-121. 